\title{
Effect of Japanese Training Camps on Life Skills Acquisition to Nurture Intelligent Wrestlers
}

\author{
Seshito Shimizu1, Kohei Shimamoto², Takashi Kawano3 ${ }^{3}$ Takeshi Kukidome ${ }^{4,5}$, \\ Hironobu Tsuchiya ${ }^{6}$
}

${ }^{1}$ Graduate School of Sport Sciences, Osaka University of Health and Sport Sciences, Osaka, Japan

${ }^{2}$ Graduate School of Education, Hyogo University of Teacher Education, Hyogo, Japan

${ }^{3}$ Touto Rehabilitation College, Tokyo, Japan

${ }^{4}$ Institute of Sports, Senshu University, Kanagawa, Japan

${ }^{5}$ Japan Institute of Sports Sciences, Tokyo, Japan

${ }^{6}$ Osaka University of Health and Sport Sciences, Osaka, Japan

Email: seshito@gmail.com

How to cite this paper: Shimizu, S., Shimamoto, K., Kawano, T., Kukidome, T., \& Tsuchiya, H. (2017). Effect of Japanese Training Camps on Life Skills Acquisition to Nurture Intelligent Wrestlers. Psychology, 8, 576-589.

https://doi.org/10.4236/psych.2017.84037

Received: February 7, 2017

Accepted: March 25, 2017

Published: March 28, 2017

Copyright $\odot 2017$ by authors and Scientific Research Publishing Inc. This work is licensed under the Creative Commons Attribution International License (CC BY 4.0).

http://creativecommons.org/licenses/by/4.0/

\begin{abstract}
The purpose of this study was to examine the interventional effects of a Japanese training camp, consisting of multiple programs designed to facilitate acquisition of life skills from the short-term and mid-term perspectives. The participants in this study were 139 top-level wrestlers in one of the four categories who participated in the Japanese Training Camp in the fiscal 2015. The scale developed by Shimamoto et al. (2013) was used to assess the life skills (LS). A pre-post comparison of the LS data obtained before and after the camp in the four categories of male and female athletes showed an overall increase in the average scores of LS in the course of the training camp. The survey was conducted one year after the participation in the training camp and indicated an overall higher life skills acquisition levels for the intervention group, and a significant difference was observed in some aspects such as "thinking ability".
\end{abstract}

\section{Keywords}

Life Skills, Dual Career, Wrestling, Educational Program, Athlete Pathway Development

\section{Introduction}

At the 30th Olympic Games in London (London Olympics) held in August of 2012, the Japanese Olympic team won seven gold medals. Four of those medals came from wrestling competitions. In the men's wrestling category, Japan has won medals in 15 consecutive Olympic Games since the 15th Olympic Games 
(Finland, Helsinki), and it has remained that wrestling is core federation in Japan elite sports.

Japan's success at wrestling competitions in recent years can be attributed to the integrated training system (NTS; the national training system) for developing athletes, which began in 2001. The NTS was based on the Basic Plan for the Promotion of Sports, and the promotion of the system for recruiting and developing junior athletes contributed to solid results in the London Olympics (Kukidome, 2014).

On the other hand, the world's leading nations tend to promote strategic recruitment and training even further. Therefore, it is necessary to refine and expand this project to win medals at international competitions including the Olympic Games consistently in the future.

To this end, the Japan Wrestling Federation (JWF) accepted the Athlete Pathway Development Program, a commissioned project from the Ministry of Education, Culture, Sports, Science and Technology outsourced from the Japan Sports Council from February of 2012 to March of 2016 and promoted the development of a system that constantly produces athletes with medal-winning potential.

To refine and expand the consistent coaching structure implemented so far under the NTS for the Junior category (U-20) and to develop the unique recruitment of the JWF, an enhancement system was pursued for the U-12, U-15, Cadet (U-17), and Junior categories.

In recent games among elite athletes, it is considered difficult to win a game solely by the efforts of the athletes and the coach; it is understood that athletes who are able to utilize the support of medical science and other benefits have an advantage. The consortium project, which has adopted the concept of "development of intelligent wrestlers", has developed an "educational program" to master the necessary disciplines and has implemented it in the course of the Athlete Development Camp (hereinafter, "Camp") (see Figure 1).

On the other hand, a great majority of top-level wrestlers get into college

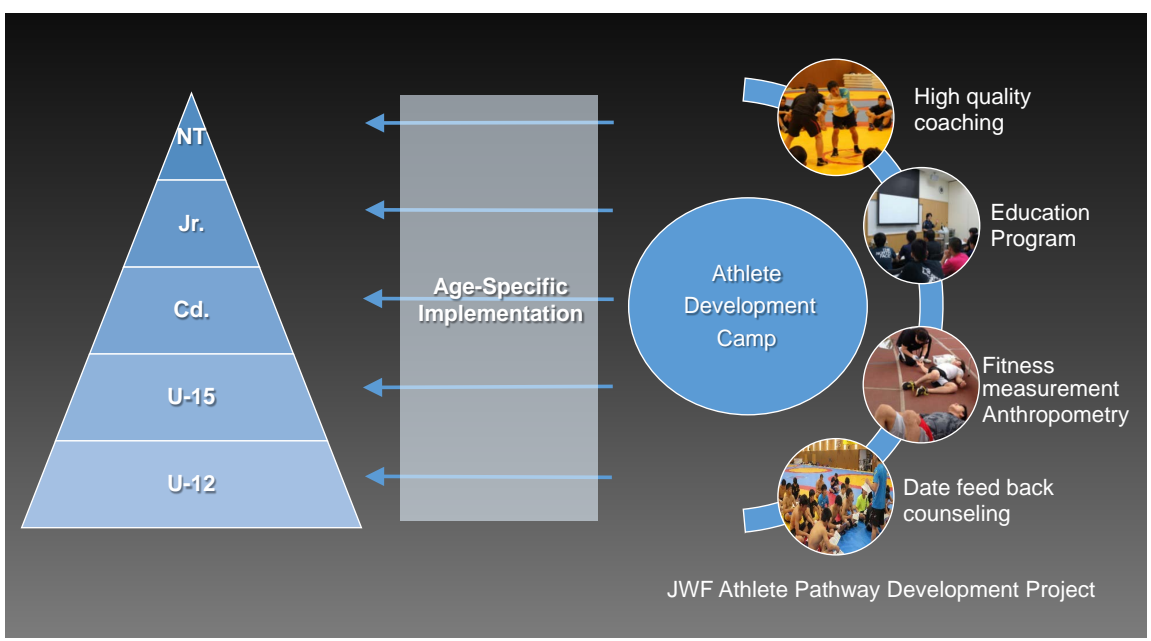

Figure 1. Japan wrestling federation athlete development camp. 
through the sports recommendation system, enhance their competitiveness, and move on to pursue a higher level. They spend most of their time during the week training and are engaged in sports at a higher level with the aim of participating in international competitions. It has been reported that time constraints due to training and other factors make it difficult for top-level college athletes to perform well academically and to find jobs. This makes it difficult for them to find a career without difficulties after their retirement from competitions (Shimizu, Takahashi, \& Kono, 2010).

With this background in mind, this project has considered life after retirement from competition and developed an educational program for athletes to acquire learnable psychosocial abilities called life skills (LS). The World Health Organization (WHO) (1997) defines LS as "the abilities for adaptive and positive behavior that enable individuals to deal effectively with the demands and challenges of everyday life." These skills enable athletes to win at a higher level and explore their careers after retirement (to realize their "Dual Career"). LS have also been described as "enhancing individual skills to overcome life events in the future" (Danish, Petitpas, \& Hale, 1995), which means that LS can also be described as abilities that prompt career development after retirement from competition.

\subsection{Relationship between LS and Career Development or Athletic Results}

The WHO (1994) has provided the model describing the broad concept of LS from the following 10 psychosocial aspects: Decision making, Problem solving, Creative thinking, Critical thinking, Effective communication, Interpersonal relationship skills, Self-awareness, Empathy, Coping with emotions, and Coping with stress.

Shimamoto, Tokairin, Murakami, \& Ishii (2013) stated that the LS acquired by former athletes comprised the following 10 psychosocial aspects: 1) stress management (e.g., trying to talk to someone when you are faced with a problem that you cannot resolve by yourself), 2) setting goals (e.g., making specific plans to achieve a goal or objective), 3) thinking carefully (e.g., being able to analyze the reasons for success and failure); 4) appreciating others (e.g., always making your gratitude clear through verbal communication), 5) communicating (e.g., getting along with older and younger students, instructors, and peers), 6) observing etiquette and manners (e.g., avoiding emotional and provocative behavior or verbal outbursts), 7) always putting in the best efforts (e.g., being able to approach simple and repetitive tasks with diligence), 8) taking responsibility for one's own behavior (e.g., trying to avoid making the same mistake twice), 9) being humble (e.g., remaining aware that you are not always right), and 10) maintaining physical health and well-being (e.g., getting enough sleep). This is based on the practical experiences of top-level instructors who have successful accomplishments such as training national champions.

Several studies that used the scale by Shimamoto et al. (2013) mentioned 
above examined the relationship between LS and career development after the end of the athletic careers of male university wrestlers.

Shimizu \& Shimamoto (2011) examined the LS acquisition levels (hereinafter, "acquisition levels") of senior athletes who had already found jobs based on their manners of job hunting. It was found that the LS acquisition levels for "appreciating others", "observing etiquette", and "taking responsibility for one's own behavior" were higher for the group that looked for specific jobs where they could leverage their athletic experiences than for the group that used some kind of influential connections.

In addition, Shimizu, Shimamoto, \& Tsuchiya (2015) conducted case study examinations on the relationship between early unofficial employment and LS for nine graduates under the same sport entry whose careers had not been determined at the time of college graduation. They found that the level for setting goals was higher at the time of graduation for participants who were able to find jobs within a year of graduation $(\mathrm{n}=4)$ than for those who were not $(\mathrm{n}=5, p<$ 0.05).

Furthermore, Shimizu, Shimamoto, Kukidome, \& Tsuchiya (2016) conducted a longitudinal study over four years on male wrestlers enrolled at a college in April of 2011. They examined the relationship between successful unofficial employment at the time of college and the change in LS over time. The results showed that the level for setting goals was significantly higher for the group who had successfully found a job at the time of graduation $(n=18)$ than for the group who had not $(n=5)$. The difference was clearly represented in the early stage of the participants' university years.

These results point to the possibility that LS acquisition not only leads to development of an active attitude toward the process of job-hunting but also exerts a positive influence in developing one's career after graduation (after retirement from competition).

On the other hand, it is often stated that most of the athletes participate in the activities, not to learn LS, but because they love the sport and want to get better (Ueno, 2005); athletes engage in games neither to acquire LS nor to smoothly develop their careers after retirement from competition but to achieve outstanding results. Therefore, positive correlations between athletic results and the LS on which the educational program places importance are desired. Concerning this point, several studies on sports such as wresting (Shimizu \& Shimamoto, 2012), judo (Shimamoto, Kakita, \& Yamamoto, 2015), and golf (Shimamoto \& Yonekawa, 2014) have shown positive correlations between both variables.

For example, Shimizu \& Shimamoto (2012) examined the relationship between LS levels of top-level male wrestlers in their freshman year prior to the intercollegiate tournament and the competition results (assigned to three groups: top 16 or higher, lower than top 16, first-round losers) by tracking their LS levels. The result showed that participants who achieved top-level athletic results -that is, those who fell under the category of top 16 or higher-had significantly higher LS levels than those who did not ( $p<0.05$ and $p<0.01$, respectively). 


\subsection{Study Purpose}

As seen above, a positive relationship was observed between LS and athletic results, and this provides an important standpoint in positioning LS acquisition as the goal of the educational program. In light of these findings, our group has developed an educational program using the results of longitudinal research by Shimizu et al. (2016) as a guide that centers on the skill of setting goals, which was, among the other LS, observed to have a positive correlation with career development after retirement from competition. This skill also had a positive correlation with athletic results and has been incorporated in the training camp, especially for younger athletes (U-12, U-15).

The camp, which lasted for three days and two nights, was conducted by the JWF project and consisted of the following programs:

1) High-quality coaching,

2) Anthropometry and measuring fitness data,

3) Data feedback and counseling,

4) Educational program.

The programs mentioned above were included to promote effective LS acquisition by wrestlers for each category. The details of the educational program implemented in fiscal years 2014 and 2015 are shown in Table 1 and Table 2, respectively.

The previous studies did not examine the effect on young top-level athletes of educational programs and camps aiming to provide valuable knowledge required to become intelligent athletes. The purpose of this study was to examine the short- and middle-term effects of the camps that held practical sessions on LS acquisition as described above.

\section{Method}

\subsection{Survey Participants and Period}

The participants in this survey were 139 top-level wrestlers in Japan who participated in the 2015 camp implemented for each category (the U-12 category:

Table 1. The implementation schedule of the 2014 camp and the content of an educational program for the cadet and junior categories.

\begin{tabular}{|c|c|c|c|c|}
\hline Category & Program title & Attribute of lecturer & Time required & Form \\
\hline \multirow[b]{2}{*}{ Cadet } & $\begin{array}{l}\text { Challenge the } \\
\text { mental training }\end{array}$ & $\begin{array}{c}\text { Scientist } \\
\text { (Sports psychology) }\end{array}$ & 1.5 hours & $\begin{array}{c}\text { Form of a } \\
\text { Group work }\end{array}$ \\
\hline & $\begin{array}{l}\text { How to take meals during } \\
\text { weight loss periods and } \\
\text { re-feeding times }\end{array}$ & $\begin{array}{c}\text { Scientist } \\
\text { (Sports Nutrition) }\end{array}$ & 1.5 hours & $\begin{array}{c}\text { Give a lecture } \\
\text { Form of a } \\
\text { discussion }\end{array}$ \\
\hline \multirow[b]{2}{*}{ Junior } & $\begin{array}{l}\text { Think about the } \\
\text { Anti-Doping }\end{array}$ & $\begin{array}{c}\text { Japan Anti-Doping } \\
\text { Agency }\end{array}$ & 1.5 hours & Give a lecture \\
\hline & $\begin{array}{l}\text { Think ahead to } \\
\text { athlete life style }\end{array}$ & $\begin{array}{c}\text { Scientist } \\
\text { (Sports Intelligence } \\
\text { Strategy) }\end{array}$ & 1.5 hours & $\begin{array}{c}\text { Give a lecture } \\
\text { Form of a } \\
\text { discussion }\end{array}$ \\
\hline
\end{tabular}


Table 2. The implementation schedule of 2015 camp and the content of an educational program for each category.

\begin{tabular}{|c|c|c|c|c|}
\hline Category & Program title & Attribute of lecturer & Time required & Form \\
\hline \multirow[b]{2}{*}{ U-12 } & $\begin{array}{l}\text { Goal achievement } \\
\text { and the process }\end{array}$ & $\begin{array}{c}\text { Olympian } \\
\text { (Gold Medalist) }\end{array}$ & 1.5 hours & $\begin{array}{l}\text { Form of a } \\
\text { Group work }\end{array}$ \\
\hline & $\begin{array}{l}\text { Think about the } \\
\text { science date }\end{array}$ & $\begin{array}{c}\text { Scientist (Sports } \\
\text { Biomecanics) and } \\
\text { National team Coach }\end{array}$ & 1.5 hours & $\begin{array}{c}\text { Give a lecture } \\
\text { Form of a } \\
\text { discussion }\end{array}$ \\
\hline \multirow[b]{2}{*}{ U-15 } & $\begin{array}{l}\text { Plan out how you will } \\
\text { get to your goal }\end{array}$ & $\begin{array}{c}\text { Scientist } \\
\text { (Sports psychology) }\end{array}$ & 1.5 hours & $\begin{array}{l}\text { Form of a } \\
\text { Group work }\end{array}$ \\
\hline & $\begin{array}{l}\text { Challenge the } \\
\text { mental training }\end{array}$ & $\begin{array}{c}\text { Scientist } \\
\text { (Sports psychology) }\end{array}$ & 1.5 hours & $\begin{array}{c}\text { Give a lecture } \\
\text { Form of a } \\
\text { discussion }\end{array}$ \\
\hline \multirow{2}{*}{ Cadet } & $\begin{array}{l}\text { Think about the } \\
\text { Intelligence }\end{array}$ & $\begin{array}{c}\text { Scientist } \\
\text { (Sports Intelligence } \\
\text { Strategy) }\end{array}$ & 1.5 hours & $\begin{array}{l}\text { Form of a } \\
\text { Group work }\end{array}$ \\
\hline & $\begin{array}{l}\text { Think about the } \\
\text { Olympism } \\
\text { (Olympic Studies) }\end{array}$ & $\begin{array}{c}\text { Scientist } \\
\text { (Sports Philosophy) }\end{array}$ & 1.5 hours & $\begin{array}{c}\text { Give a lecture } \\
\text { Form of a } \\
\text { discussion }\end{array}$ \\
\hline \multirow[b]{2}{*}{ Junior } & Media training & Announcer & 1.5 hours & $\begin{array}{l}\text { Form of a } \\
\text { Group work }\end{array}$ \\
\hline & $\begin{array}{l}\text { Think about the } \\
\text { self conditioning }\end{array}$ & Physical therapist & 1.5 hours & $\begin{array}{l}\text { Give a lecture } \\
\text { Form of a } \\
\text { discussion }\end{array}$ \\
\hline
\end{tabular}

10 male athletes, average age $11.4 \pm 0.6$ and 10 female athletes, average age 11.1 \pm 0.5 ; the U-15 category: 13 male athletes, average age $14.1 \pm 1.1$ and 13 female athletes, average age $13.6 \pm 1.0$; the Cadet category: 30 male athletes, average age $15.7 \pm 1.0$ and 13 female athletes, average age $16.0 \pm 0.9$; the Junior category: 37 male athletes, average age $18.5 \pm 0.8$ and 13 female athletes, average age $17.8 \pm$ $0.9)$.

\subsection{Administrative Procedure}

Before conducting the survey, we explained the purpose of the study to the managers and coaches of the club they belonged to as well as their parents and obtained written informed consent from the parents. Each survey was administered based on the concurrent method. The forms were distributed after providing a thorough explanation to the participants, and these forms were collected as soon as the participants completed them. Furthermore, all surveys were conducted in the registered form. This study was reviewed and approved by the ethics review committee of Osaka University of Health and Sport Sciences.

\subsection{Survey Contents}

Appraisal Scale for Life Skills in College Student Athletes (Shimamoto et al., 2013)

Based on previous studies (Shimizu \& Shimamoto, 2011, 2012; Shimizu et al., 
2015 , 2016) the athletes' LS levels were assessed using the scale developed by Shimamoto et al. (2013). This scale measures the 10 important LS such as "setting goals", "thinking carefully", and "communicating" as described in the previous section. Participants responded by rating on a scale from 1 to 4 where "1" indicated "Strongly disagree" and "4" indicated "Strongly agree"; higher rating scores indicated higher skill levels.

Although this scale was developed based on the data obtained from university athletes, it was adopted for assessing the athletes' LS in each category since it can assess many LS at the same time for athletes (Shimamoto \& Yonekawa, 2014), and it is possible to evaluate each extremely valuable LS for all age athletes.

\subsection{Analysis Strategy}

The effects of LS acquisition from the camps were examined in Study 1 and Study 2 below. The former focused on the 2015 camp while the latter focused on the 2014 camp, which was implemented in the same manner as that in 2015 (see Figure 2). For both studies, t-tests were conducted to examine the effect of LS acquisition. The IBM SPSS Statistics software (version 20.0) was used for all analyses. Statistical significance was set at $5 \%$.

Study 1 was a short-term investigation implemented for each category to compare the pre-post LS data obtained before and after the 2015 camp. Study 2 was a mid-term investigation implemented for the Cadet and Junior categories where the data obtained before the 2015 camp were compared with the intervention group that participated in both the 2014 and 2015 camps as well as the non-intervention group that participated in the 2015 camp.

\section{Results}

\subsection{Short-Term Investigation for Each Category}

The results of the pre-post LS data comparison of male and female participants for each category are shown in Table 3 and Table 4, respectively.

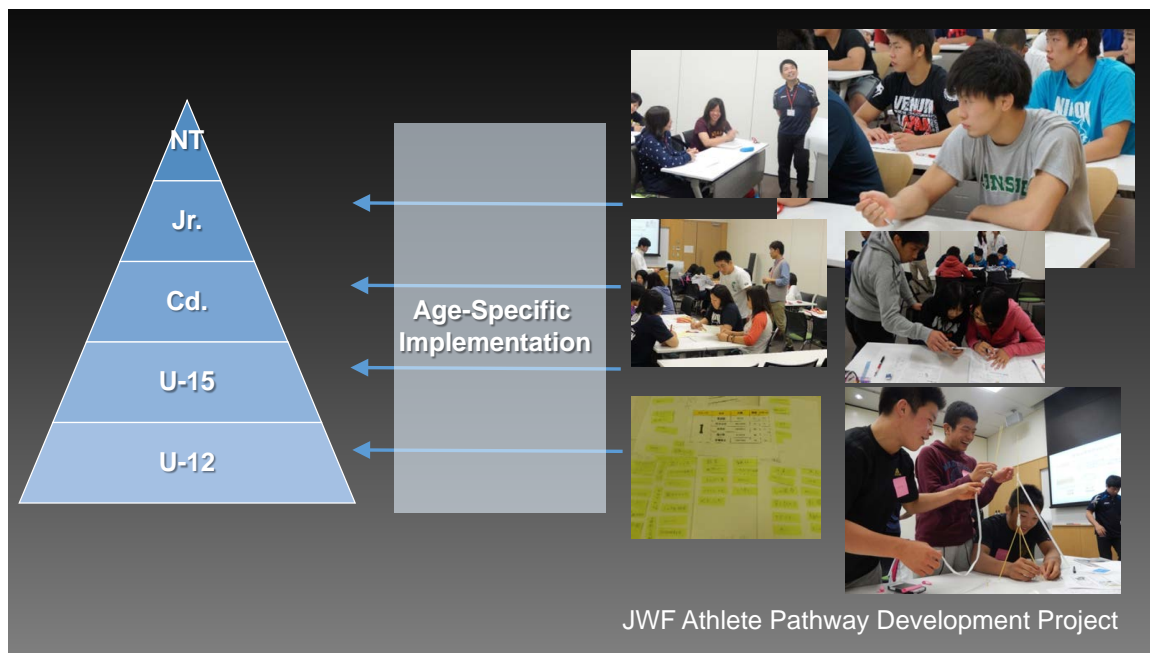

Figure 2. Education program. 


\section{Male Participants}

\section{The U-12 and U-15 categories}

For both categories, the results of the repeated t-tests indicated that none of the LS significantly enhanced the mean score. Furthermore, the mean score of "setting goals"-one of the main skills to be acquired during the camp-was somewhat enhanced.

\section{The Cadet and Junior categories}

For both categories, it was found that the mean score was significantly enhanced for the skill of "maintaining physical health and well-being." Besides, it was seen that the mean score was significantly enhanced for the skills of "setting goals" and "thinking carefully" for the Cadet category. For the Junior category, the scores had significantly increased for the skills of "communicating," "always making one's best efforts" (hereinafter, "best efforts"), and "taking responsibility for one's own behavior" (hereinafter, "taking responsibility"). On the other hand, the mean score obtained on the skill of "taking responsibility" had significantly declined for the Cadet category.

Table 3. The results of the pre-post LS data comparison of male participants for each category.

\begin{tabular}{|c|c|c|c|c|c|c|c|c|c|c|c|c|}
\hline & \multicolumn{3}{|c|}{ Junior } & \multicolumn{3}{|c|}{ Cadet } & \multicolumn{3}{|c|}{$\mathrm{U}-15$} & \multicolumn{3}{|c|}{$\mathrm{U}-12$} \\
\hline & \multicolumn{2}{|c|}{ Mean value (SD) } & \multirow[b]{2}{*}{ t value } & \multicolumn{2}{|c|}{ Mean value (SD) } & \multirow[b]{2}{*}{ t value } & \multicolumn{2}{|c|}{ Mean value (SD) } & \multirow[b]{2}{*}{ t value } & \multicolumn{2}{|c|}{ Mean value (SD) } & \multirow[b]{2}{*}{$\mathrm{t}$ value } \\
\hline & $\begin{array}{c}\text { Pre } \\
(\mathrm{n}=37)\end{array}$ & $\begin{array}{c}\text { Post } \\
(\mathrm{n}=37)\end{array}$ & & $\begin{array}{c}\text { Pre } \\
(n=30)\end{array}$ & $\begin{array}{c}\text { Post } \\
(\mathrm{n}=30)\end{array}$ & & $\begin{array}{c}\text { Pre } \\
(n=13)\end{array}$ & $\begin{array}{c}\text { Post } \\
(n=13)\end{array}$ & & $\begin{array}{c}\text { Pre } \\
(n=10)\end{array}$ & $\begin{array}{c}\text { Post } \\
(\mathrm{n}=10)\end{array}$ & \\
\hline Stress management & $\begin{array}{l}13.14 \\
(2.77)\end{array}$ & $\begin{array}{l}13.41 \\
(2.50)\end{array}$ & 0.97 & $\begin{array}{l}11.97 \\
(2.47)\end{array}$ & $\begin{array}{l}11.83 \\
(2.90)\end{array}$ & 0.39 & $\begin{array}{l}12.62 \\
(2.69)\end{array}$ & $\begin{array}{l}13.00 \\
(2.12)\end{array}$ & 0.67 & $\begin{array}{l}12.80 \\
(2.78)\end{array}$ & $\begin{array}{l}12.60 \\
(3.47)\end{array}$ & 0.28 \\
\hline Setting goals & $\begin{array}{l}10.65 \\
(2.21)\end{array}$ & $\begin{array}{l}10.92 \\
(2.36)\end{array}$ & 0.82 & $\begin{array}{l}11.00 \\
(2.60)\end{array}$ & $\begin{array}{l}11.37 \\
(2.57)\end{array}$ & 1.41 & $\begin{array}{l}11.69 \\
(1.80)\end{array}$ & $\begin{array}{l}12.85 \\
(2.08)\end{array}$ & 1.90 & $\begin{array}{l}11.90 \\
(2.08)\end{array}$ & $\begin{array}{l}13.10 \\
(1.97)\end{array}$ & 1.81 \\
\hline Thinking carefully & $\begin{array}{l}12.89 \\
(1.85)\end{array}$ & $\begin{array}{l}13.16 \\
(1.77)\end{array}$ & 1.02 & $\begin{array}{l}12.70 \\
(1.82)\end{array}$ & $\begin{array}{l}13.43 \\
(1.59)\end{array}$ & $2.67^{\star}$ & $\begin{array}{l}12.15 \\
(2.03)\end{array}$ & $\begin{array}{l}12.46 \\
(2.03)\end{array}$ & 0.44 & $\begin{array}{l}13.80 \\
(1.14)\end{array}$ & $\begin{array}{l}13.80 \\
(1.23)\end{array}$ & 0.00 \\
\hline Appreciating others & $\begin{array}{l}14.05 \\
(1.97)\end{array}$ & $\begin{array}{l}14.30 \\
(1.85)\end{array}$ & 1.25 & $\begin{array}{l}14.57 \\
(1.68)\end{array}$ & $\begin{array}{l}15.07 \\
(1.46)\end{array}$ & $2.06^{*}$ & $\begin{array}{l}14.08 \\
(1.50)\end{array}$ & $\begin{array}{l}14.15 \\
(1.21)\end{array}$ & 0.20 & $\begin{array}{l}14.50 \\
(1.18)\end{array}$ & $\begin{array}{l}14.40 \\
(1.96)\end{array}$ & 0.23 \\
\hline Communicating & $\begin{array}{l}13.46 \\
(2.02)\end{array}$ & $\begin{array}{l}14.16 \\
(1.80)\end{array}$ & $2.38^{*}$ & $\begin{array}{l}14.60 \\
(1.50)\end{array}$ & $\begin{array}{l}14.80 \\
(1.47)\end{array}$ & 0.92 & $\begin{array}{l}14.23 \\
(2.59)\end{array}$ & $\begin{array}{l}14.15 \\
(1.95)\end{array}$ & 0.21 & $\begin{array}{l}13.20 \\
(2.62)\end{array}$ & $\begin{array}{l}13.30 \\
(2.31)\end{array}$ & 0.15 \\
\hline $\begin{array}{l}\text { Maintaining etiquette } \\
\text { and manners }\end{array}$ & $\begin{array}{l}13.70 \\
(2.22)\end{array}$ & $\begin{array}{l}14.30 \\
(2.03)\end{array}$ & 1.79 & $\begin{array}{l}14.73 \\
(1.28)\end{array}$ & $\begin{array}{l}14.23 \\
(1.74)\end{array}$ & 1.80 & $\begin{array}{l}14.54 \\
(1.05)\end{array}$ & $\begin{array}{l}14.92 \\
(1.44)\end{array}$ & 0.84 & $\begin{array}{l}14.80 \\
(1.69)\end{array}$ & $\begin{array}{l}14.60 \\
(1.71)\end{array}$ & 0.48 \\
\hline $\begin{array}{l}\text { Always making one's } \\
\text { best efforts }\end{array}$ & $\begin{array}{l}12.46 \\
(1.99)\end{array}$ & $\begin{array}{l}13.46 \\
(1.89)\end{array}$ & $3.33^{\star *}$ & $\begin{array}{l}13.33 \\
(1.81)\end{array}$ & $\begin{array}{l}13.53 \\
(1.98)\end{array}$ & 0.92 & $\begin{array}{l}13.62 \\
(1.26)\end{array}$ & $\begin{array}{l}13.54 \\
(1.39)\end{array}$ & 0.32 & $\begin{array}{l}15.00 \\
(1.49)\end{array}$ & $\begin{array}{l}14.50 \\
(1.43)\end{array}$ & 1.00 \\
\hline $\begin{array}{l}\text { Taking responsibility } \\
\text { for one's own behavior }\end{array}$ & $\begin{array}{l}13.35 \\
(1.99)\end{array}$ & $\begin{array}{l}14.03 \\
(1.76)\end{array}$ & $4.35^{\star * *}$ & $\begin{array}{l}14.43 \\
(1.48)\end{array}$ & $\begin{array}{l}14.10 \\
(1.84)\end{array}$ & $2.07^{\star}$ & $\begin{array}{l}13.92 \\
(1.50)\end{array}$ & $\begin{array}{l}14.08 \\
(1.55)\end{array}$ & 0.38 & $\begin{array}{l}14.40 \\
(1.17)\end{array}$ & $\begin{array}{l}14.50 \\
(1.35)\end{array}$ & 0.25 \\
\hline $\begin{array}{l}\text { Maintaining physical } \\
\text { health and well-being }\end{array}$ & $\begin{array}{l}12.24 \\
(1.91)\end{array}$ & $\begin{array}{l}13.51 \\
(2.23)\end{array}$ & $5.14^{\star * *}$ & $\begin{array}{l}12.90 \\
(1.83)\end{array}$ & $\begin{array}{l}13.47 \\
(1.98)\end{array}$ & $2.10^{*}$ & $\begin{array}{l}12.85 \\
(2.30)\end{array}$ & $\begin{array}{l}12.38 \\
(2.33)\end{array}$ & 0.82 & $\begin{array}{l}13.80 \\
(1.75)\end{array}$ & $\begin{array}{l}14.10 \\
(2.02)\end{array}$ & 0.45 \\
\hline
\end{tabular}

Note: ${ }^{\star} p<0.05 ;{ }^{\star \star} p<0.01 ;{ }^{\star * \star} p<0.001$. 
Table 4. The results of the pre-post LS data comparison of female participants for each category.

\begin{tabular}{|c|c|c|c|c|c|c|c|c|c|c|c|c|}
\hline & \multicolumn{3}{|c|}{ Junior } & \multicolumn{3}{|c|}{ Cadet } & \multicolumn{3}{|c|}{$\mathrm{U}-15$} & \multicolumn{3}{|c|}{$\mathrm{U}-12$} \\
\hline & \multicolumn{2}{|c|}{ Mean value (SD) } & \multirow[b]{2}{*}{ t value } & \multicolumn{2}{|c|}{ Mean value (SD) } & \multirow[b]{2}{*}{ t value } & \multicolumn{2}{|c|}{ Mean value (SD) } & \multirow[b]{2}{*}{$\mathrm{t}$ value } & \multicolumn{2}{|c|}{ Mean value (SD) } & \multirow[b]{2}{*}{ t value } \\
\hline & $\begin{array}{c}\text { Pre } \\
(\mathrm{n}=13)\end{array}$ & $\begin{array}{c}\text { Post } \\
(\mathrm{n}=13)\end{array}$ & & $\begin{array}{c}\text { Pre } \\
(\mathrm{n}=13)\end{array}$ & $\begin{array}{c}\text { Post } \\
(n=13)\end{array}$ & & $\begin{array}{c}\text { Pre } \\
(n=13)\end{array}$ & $\begin{array}{c}\text { Post } \\
(n=13)\end{array}$ & & $\begin{array}{c}\text { Pre } \\
(\mathrm{n}=10)\end{array}$ & $\begin{array}{c}\text { Post } \\
(\mathrm{n}=10)\end{array}$ & \\
\hline Stress management & $\begin{array}{l}12.85 \\
(2.58)\end{array}$ & $\begin{array}{l}13.08 \\
(2.50)\end{array}$ & 0.56 & $\begin{array}{l}13.69 \\
(2.53)\end{array}$ & $\begin{array}{l}13.54 \\
(2.30)\end{array}$ & 0.41 & $\begin{array}{l}13.54 \\
(2.18)\end{array}$ & $\begin{array}{l}13.92 \\
(2.47)\end{array}$ & 0.73 & $\begin{array}{l}14.20 \\
(3.65)\end{array}$ & $\begin{array}{l}14.70 \\
(3.77)\end{array}$ & 2.24 \\
\hline Setting goals & $\begin{array}{l}11.38 \\
(2.40)\end{array}$ & $\begin{array}{l}12.15 \\
(2.19)\end{array}$ & $2.38^{*}$ & $\begin{array}{l}13.00 \\
(2.24)\end{array}$ & $\begin{array}{l}13.23 \\
(2.65)\end{array}$ & 0.82 & $\begin{array}{l}11.38 \\
(3.01)\end{array}$ & $\begin{array}{l}14.31 \\
(1.70)\end{array}$ & $4.46^{\star *}$ & $\begin{array}{l}11.60 \\
(1.58)\end{array}$ & $\begin{array}{l}10.70 \\
(2.16)\end{array}$ & 1.59 \\
\hline Thinking carefully & $\begin{array}{l}11.54 \\
(1.85)\end{array}$ & $\begin{array}{l}12.15 \\
(2.64)\end{array}$ & 0.98 & $\begin{array}{l}13.08 \\
(2.02)\end{array}$ & $\begin{array}{l}13.38 \\
(2.06)\end{array}$ & 1.08 & $\begin{array}{l}11.77 \\
(2.62)\end{array}$ & $\begin{array}{l}12.85 \\
(1.07)\end{array}$ & 1.75 & $\begin{array}{l}12.80 \\
(1.81)\end{array}$ & $\begin{array}{l}12.00 \\
(1.89)\end{array}$ & $2.75^{\star}$ \\
\hline Appreciating others & $\begin{array}{l}13.92 \\
(1.66)\end{array}$ & $\begin{array}{l}14.31 \\
(2.06)\end{array}$ & 1.16 & $\begin{array}{l}14.62 \\
(2.06)\end{array}$ & $\begin{array}{l}15.23 \\
(1.30)\end{array}$ & 1.48 & $\begin{array}{l}13.77 \\
(2.09)\end{array}$ & $\begin{array}{l}14.46 \\
(2.15)\end{array}$ & 2.00 & $\begin{array}{l}14.60 \\
(1.35)\end{array}$ & $\begin{array}{l}15.20 \\
(1.14)\end{array}$ & 2.25 \\
\hline Communicating & $\begin{array}{l}12.69 \\
(1.70)\end{array}$ & $\begin{array}{l}12.69 \\
(2.18)\end{array}$ & 0.00 & $\begin{array}{l}14.46 \\
(2.44)\end{array}$ & $\begin{array}{l}14.54 \\
(1.98)\end{array}$ & 0.23 & $\begin{array}{l}13.69 \\
(1.93)\end{array}$ & $\begin{array}{l}14.00 \\
(1.87)\end{array}$ & 0.84 & $\begin{array}{l}14.10 \\
(0.74)\end{array}$ & $\begin{array}{l}14.10 \\
(1.66)\end{array}$ & 0.00 \\
\hline $\begin{array}{l}\text { Maintaining etiquette } \\
\text { and manners }\end{array}$ & $\begin{array}{l}14.23 \\
(2.39)\end{array}$ & $\begin{array}{l}14.62 \\
(1.76)\end{array}$ & 0.53 & $\begin{array}{l}14.69 \\
(1.55)\end{array}$ & $\begin{array}{l}15.46 \\
(1.39)\end{array}$ & $2.74^{\star}$ & $\begin{array}{l}14.15 \\
(2.64)\end{array}$ & $\begin{array}{l}15.23 \\
(1.42)\end{array}$ & $2.50^{*}$ & $\begin{array}{l}13.70 \\
(2.26)\end{array}$ & $\begin{array}{l}15.00 \\
(0.82)\end{array}$ & 1.57 \\
\hline $\begin{array}{l}\text { Always making one's } \\
\text { best efforts }\end{array}$ & $\begin{array}{l}12.69 \\
(1.32)\end{array}$ & $\begin{array}{l}13.23 \\
(2.13)\end{array}$ & 1.40 & $\begin{array}{l}13.54 \\
(2.18)\end{array}$ & $\begin{array}{l}13.85 \\
(2.34)\end{array}$ & 1.30 & $\begin{array}{l}13.08 \\
(2.40)\end{array}$ & $\begin{array}{l}14.00 \\
(1.83)\end{array}$ & $2.22^{*}$ & $\begin{array}{l}13.70 \\
(2.45)\end{array}$ & $\begin{array}{l}13.40 \\
(1.96)\end{array}$ & 0.50 \\
\hline $\begin{array}{c}\text { Taking responsibility for } \\
\text { one's own behavior }\end{array}$ & $\begin{array}{l}12.77 \\
(1.48)\end{array}$ & $\begin{array}{l}13.23 \\
(1.59)\end{array}$ & 1.59 & $\begin{array}{l}14.00 \\
(1.96)\end{array}$ & $\begin{array}{l}14.23 \\
(2.05)\end{array}$ & 1.00 & $\begin{array}{l}12.77 \\
(1.09)\end{array}$ & $\begin{array}{l}14.38 \\
(1.26)\end{array}$ & $7.58^{* * *}$ & $\begin{array}{l}13.60 \\
(1.07)\end{array}$ & $\begin{array}{l}13.90 \\
(1.91)\end{array}$ & 0.52 \\
\hline $\begin{array}{l}\text { Maintaining physical } \\
\text { health and well-being }\end{array}$ & $\begin{array}{l}12.31 \\
(1.97)\end{array}$ & $\begin{array}{l}12.15 \\
(1.99)\end{array}$ & 0.49 & $\begin{array}{l}14.00 \\
(2.12)\end{array}$ & $\begin{array}{l}14.46 \\
(1.45)\end{array}$ & 1.59 & $\begin{array}{l}13.00 \\
(1.87)\end{array}$ & $\begin{array}{l}13.92 \\
(1.89)\end{array}$ & $2.52^{*}$ & $\begin{array}{l}13.70 \\
(1.34)\end{array}$ & $\begin{array}{l}13.50 \\
(1.51)\end{array}$ & 0.31 \\
\hline
\end{tabular}

Note: ${ }^{*} p<0.05 ;{ }^{* *} p<0.01 ;{ }^{* * *} p<0.001$.

\section{Female Participants}

\section{The U-12 category}

On "setting goals," the target LS for this category, the mean score had somewhat declined. Moreover, it was seen that the mean score of "thinking carefully" had also significantly declined.

\section{The U-15 category}

First, the results showed that the mean score of "setting goals," the target LS on this category, had been significantly enhanced. In addition, it was observed that the mean score was significantly enhanced on several LS such as "observing etiquette," "best efforts," "taking responsibility," "being humble," and "maintaining physical health and well-being".

\section{The Cadet and Junior categories}

For both categories, it was seen that the mean score was significantly enhanced for the skill of "observing etiquette" for the Cadet category and "setting goals" for the Junior category. 


\subsection{Middle-Term Investigation for the Cadet and Junior Categories}

The results of the pre LS data comparison of the 2015 camp between the intervention and non-intervention groups are shown in Table 5.

\section{The Cadet category}

For the intervention group, the mean score of "taking responsibility" was significantly higher than that of the non-intervention group among male participants, and the mean score was marginally higher for the skill of "best efforts" among female participants.

\section{The Junior category}

For both male and female participants, the mean score of "thinking carefully" was marginally higher for the intervention group than for the non-intervention group. Moreover, for female participants, the mean score of "being humble" was marginally higher for the intervention group than for the non-intervention group.

Table 5. The results of the pre LS data comparison of the 2015 camp between the intervention and non-intervention groups for cadet and junior categories.

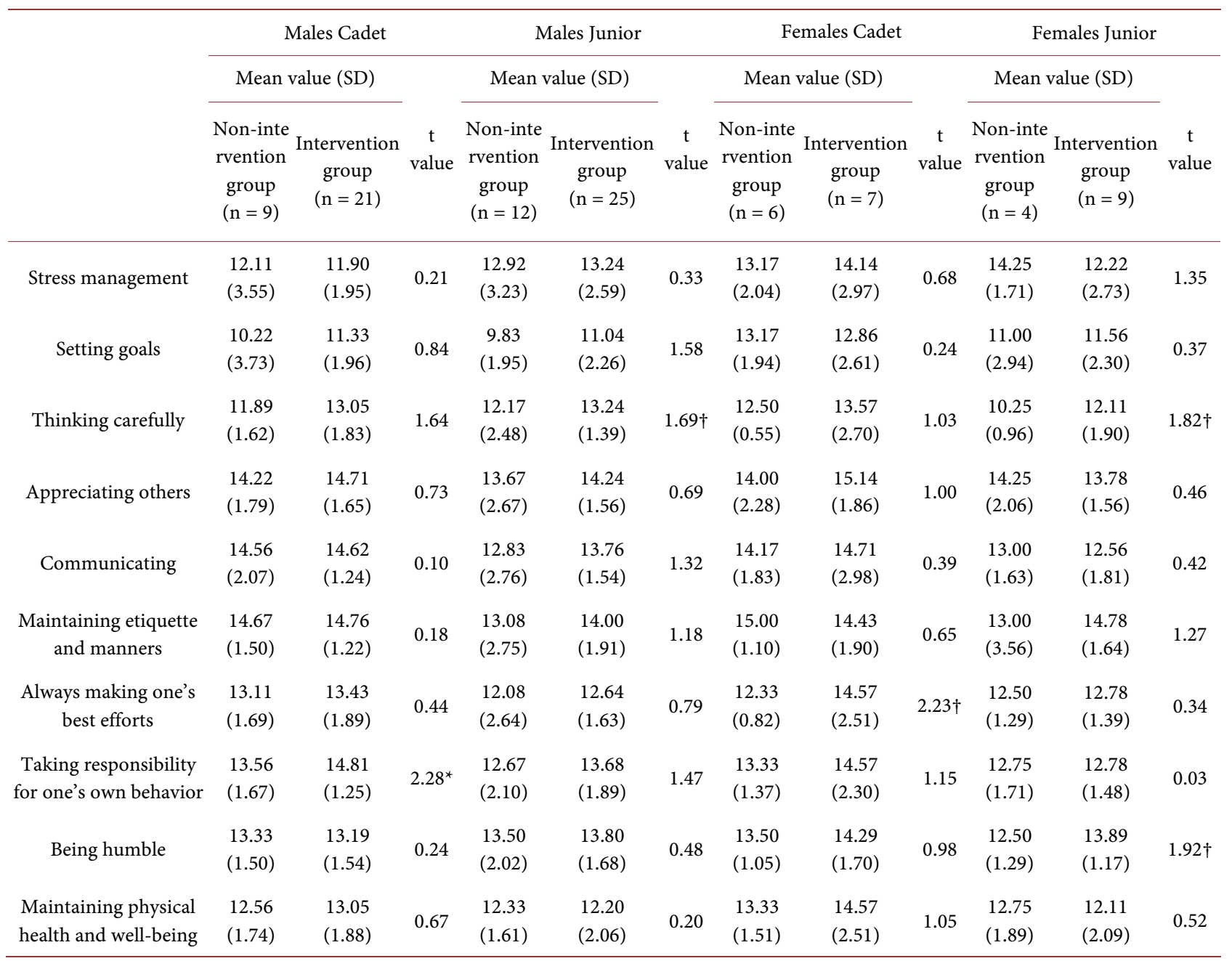

Note: ${ }^{\dagger} p<0.10 ;{ }^{\star} p<0.05$. 


\section{Discussion}

\subsection{LS Acquisition Level for Each Category}

This study utilized the LS assessment scale developed by Shimamoto et al. (2013), and conducted short- and mid-term examinations of top-level athletes from all age groups who attended training camps. The results showed that, in some aspects of the LS, the U-12 and U-15 categories had higher mean scores than the Cadet and Junior categories for both male and female participants (Table 3 and Table 4).

The difference in experience may have affected the results. In other words, athletes in the Cadet and Junior categories have gained experience through many games, and many have recognized their abilities relatively accurately, which, in turn, may have led them to adopt more stringent assessment criteria while answering the questions. For these reasons, we can say that comparison of mean LS values between different age groups does not necessarily lead to a precise insight. In addition, the scale developed by Shimamoto et al. (2013) can assess LS required for athletes in general; younger athletes may not understand the meaning of some parts of the questions in the scale. Thus, in what follows, we will examine the results of the short- and mid-term surveys of the Cadet and Junior categories.

\subsection{Short-Term Effects on LS Acquisition by Camp Participation}

We compared the LS data obtained before and after camp participation from four categories of both male and female athletes of the Cadet and Junior categories. Overall, the result shows improvements in the mean values over the course of the training camp (Table 3 and Table 4). This suggests that the training camp programs comprised "high-quality coaching," "shape and fitness measurement," "feedback of measured data," and "educational program" for LS acquisition.

When we focused on the effect of "setting goals," the LS seen in wrestlers according to previous studies (Shimizu \& Shimamoto, 2012; Shimizu et al., 2015, 2016), it was found to be positively correlated with the achievement of high placement as well as career development after retirement from competition; male Cadets and female Juniors were the only categories that exhibited significant improvements in the mean values throughout the training camp. Furthermore, the mean value improved from 10.65 to 10.92 for the male Junior category and from 13.0 to 13.23 for the female Cadet category, although the improvement in the latter was not high. As for the educational program, although the program for these two categories was not directly aimed at helping athletes acquire the "setting goals" skill as it was for the U-12 and U-15 categories (Table 2), it was seen to have a positive influence on the acquisition of LS important for wrestlers. This suggests that the educational program and the training camp in this project were appropriate in our pursuit of developing athletes who could realize a "Dual Career". It is necessary, therefore, to discuss details of the experiences of acquiring the "setting goals" skill through interviews, surveys, and so on. 


\subsection{Middle-Term Effects on LS Acquisition by Participating in the Camp}

Overall, the intervention group had higher LS acquisition levels for the male and female athletes of the Cadet and Junior categories; marginal differences were observed in some aspects such as "thinking carefully". This suggests that the positive effect of the training camp held in the previous fiscal year persists even after a certain period has passed. Of course, we should refrain from overestimating this result; nevertheless, we can say that it suggests that training camps promoting LS acquisition at a younger age are also desirable for nurturing top athletes to enable them to realize a "Dual Career".

The JWF has changed the athletes' ages for receiving training from U-20 to U-12 to expand and refine the consistent coaching structure, and this direction can be considered appropriate.

\subsection{Gender Differences in the Effect of LS Acquisition by Camp Participation}

Although the training camps for the Cadet and Junior categories were conducted separately for both women and men, the structure of the training camp and the educational program were the same for both male and female athletes. However, in the short-term examination, no aspects of LS had a significant improvement in the mean value for both male and female athletes. Even in the mid-term examination, the mean scores of the aspects of LS that were significantly higher for the Cadet intervention differed for male and female athletes. The gender difference observed in the effect of LS acquisition through the training camp provides important knowledge to discuss effective intervention strategies toward LS acquisition for both male and female athletes. On the other hand, we cannot identify the cause of the observed gender differences in LS acquisition from the results obtained in this study alone. It is necessary to examine whether such gender differences are seen in the athletes' purposes for participating in the training camp as well as in the content of goals they set.

In this study, we examined the effect of LS acquisition over the course of a training camp. It is of crucial importance, therefore, to examine by gender and age the process of acquiring LS through the camp.

\section{Study Limitations and Primary Challenges}

The present qualitative study had a few limitations. First, the training camps were conducted together, although the content of the education program for each category differed. Second, the structure of trainers who attended the training camp differed in every session; therefore, we cannot be sure that the method and effectiveness of speaking to athletes during the camp and of coaching were always the same. Therefore, we had to control the effect of the trainers on LS acquisition as much as possible and to examine the process of the intervention through the training camp leading to LS acquisition using the qualitative research model. Third, we had to examine from the long-term perspective how LS 
acquisition through the training camp influenced the behavioral changes of athletes, their subsequent performances, and their career development after retirement from competition. Finally, the LS assessment scale (Shimamoto et al., 2013) used in this study was developed based on data of college athletes; therefore, younger participants (the U-12 and U-15 categories) may not have correctly understood the meaning of the questions. It is important to discuss the development of an LS assessment scale for athletes of all age groups to carry out the research concerning LS acquisition systematically with the goal of nurturing athletes who can realize a "Dual Career".

\section{References}

Danish, S. J., Petitpas, A. J., \& Hale, B. D. (1995). Psychological Interventions: A Life Development Model. In S. M. Murphy (Ed.), Sport Psychology Interventions (pp. 9-38). Champaign, IL: Human Kinetics.

Kukidome, T. (2014). New Function Necessary in Elite Sport Is Bridging among All Related Stakeholders to Work Effectively: In the Case of Technical Director in Wrestling. Journal of Training Science for Exercise and Sport, 25, 165-172.

Shimamoto, K., Kakita, K., \& Yamamoto, K. (2015). The Relationships between Life Skills and Competition Results in University Judo Practitioners. SSF Journal of Sports for Everyone, 280-289.

http://www.ssf.or.jp/Portals/0/resources/encourage/grant/pdf/research14_6-06.pdf\#sea $\underline{\text { rch='The+relationships+between+life+skills+and+competition+results+in+university }}$ +judo+practitioners $\% \mathrm{EF} \% \mathrm{BC} \% 8 \mathrm{E}^{\prime}$

Shimamoto, K., Tokairin, Y., Murakami, K., \& Ishii, M. (2013). Appraisal of Required Life Skills for Athletes: A Scale Development on College Student Athletes. Japanese Journal of Sport Psychology, 40, 13-30. https://doi.org/10.4146/jjspopsy.2012-1204

Shimamoto, K., \& Yonekawa, N. (2014). The Relationship between Life Skills and Competition Results in High School Golfers. Japan Journal of Physical Education, Health and Sport Sciences, 59, 817-827. https://doi.org/10.5432/jjpehss.13049 https://www.jstage.jst.go.jp/article/jjpehss/59/2/59_13049/_article/

Shimizu, S., \& Shimamoto, K. (2011). The Relationship between Career Development and Life Skills Acquisition in Top Student Athletes. Bulletin of Nippon Sport Science University, 41, 111-116.

https://nittaidai.repo.nii.ac.jp/?action=pages_view_main\&active_action=repository_vie w_main_item_detail\&item_id=1208\&item_no=1\&page_id=13\&block_id=21

Shimizu, S., \& Shimamoto, K. (2012). The Relationship between Life Skills Acquisition and Athletic Performance in University Male Wrestlers. Essays on Executive Management in Physical Education, 4, 47-53.

Shimizu, S., Takahashi, Y., \& Kono, I. (2010). A Comparison of Employment Situation of University Athletic Clubs Based on Differences in Instruction and Management: A Case of Wrestlers. Journal of Japan Society of Sports Industry, 20, 119-129.

https://doi.org/10.5997/sposun.20.119

Shimizu, S., Shimamoto, K., Kukidome, T., \& Tsuchiya, H. (2016). Changes in Life Skills of Top College Athletes over Four Years and Its Relation to Career Outcomes. International Journal of Sport and Health Science, 14, 72-78.

https://doi.org/10.5432/ijshs.201516

Shimizu, S., Shimamoto, K., \& Tsuchiya, H. (2015). The Relationships between Life Skills and Post-Graduation Employment for Top College Student Wrestlers in Japan. Inter- 
national Journal of Sport and Health Science, 13, 17-22.

https://www.jstage.jst.go.jp/article/ijshs/13/0/13_201411/_article https://doi.org/10.5432/ijshs.201411

Ueno, K. (2005). Yuusu senshu wo taisho to shita raifu sukiru puroguram [Life Skill Programs for Athletes in Their Youth]. Journal of Health, Physical Education and Recreation, 55, 101-105.

World Health Organization (WHO) (1994). Life Skills Education in Schools. Geneva. http://www.asksource.info/pdf/31181_lifeskillsed_1994.pdf\#search='Life+skills+educati on+in+schools'

Submit or recommend next manuscript to SCIRP and we will provide best service for you:

Accepting pre-submission inquiries through Email, Facebook, LinkedIn, Twitter, etc. A wide selection of journals (inclusive of 9 subjects, more than 200 journals) Providing 24-hour high-quality service User-friendly online submission system Fair and swift peer-review system Efficient typesetting and proofreading procedure Display of the result of downloads and visits, as well as the number of cited articles Maximum dissemination of your research work

Submit your manuscript at: http://papersubmission.scirp.org/

Or contact psych@scirp.org 